\title{
Design, synthesis and biomedical evaluation of mostotrin, a new water soluble tryptanthrin derivative
}

\author{
ALEXANDER POPOV $^{1,2^{*}}$, ANNA KLIMOVICH ${ }^{1,2^{*}}$, OLGA STYSHOVA ${ }^{1,2}$, TAISIYA MOSKOVKINA ${ }^{3}$, \\ ANDREY SHCHEKOTIKHIN ${ }^{4 *}$, NATALIA GRAMMATIKOVA ${ }^{4}$, LYUBOV DEZHENKOVA ${ }^{4}$, DMITRY KALUZHNY $^{5}$, \\ PETER DERIABIN $^{5}$, ANDREY GERASIMENKO ${ }^{6}$, ANATOLY UDOVENKO ${ }^{6}$ and VALENTIN STONIK ${ }^{1-3^{*}}$ \\ Departments of ${ }^{1}$ Biotechnology and ${ }^{2}$ Marine Natural Compounds Chemistry, G.B. Elyakov Pacific \\ Institute of Bioorganic Chemistry, Far Eastern Branch of The Russian Academy of Sciences, Vladivostok 69022; ${ }^{3}$ School \\ of Natural Sciences, Far Eastern Federal University, Vladivostok 690920; ${ }^{4}$ Department of Chemical \\ Transformation of Antibiotics, Gauze Research Institute for The Search for New Antibiotics, Russian Academy of \\ Medical Sciences, Moscow 119435; ${ }^{5}$ Department of DNA-protein Interactions, Engelhardt Institute of Molecular \\ Biology, Russian Academy of Sciences, Moscow 119991; ${ }^{6}$ Department of of X-ray Analysis, Institute of Chemistry, \\ Far Eastern Branch of The Russian Academy of Sciences, Vladivostok 69022, Russia
}

Received February 26, 2020; Accepted June 18, 2020

DOI: $10.3892 / \mathrm{ijmm} .2020 .4693$

\begin{abstract}
Mostotrin (MT), a novel compound, at least five orders of magnitude more soluble in water than its mother substance, was designed and synthesised from tryptanthrin (TR). Its structure was established by nuclear magnetic resonance and mass spectrometry data and confirmed by X-ray analysis, revealing that MT is a pentacyclic product with an additional pseudo-cycle formed with the participation of one intramolecular hydrogen bond. Antimicrobial activity and cytotoxic action against tumour cells in vitro, as well as anti-tumour effects, acute toxicity and anti-inflammatory activities in vivo, were evaluated. Antimicrobial properties of MT against Mycobacterium spp and Bacillus cereus ATCC 10702 appeared to be the same as that of TR, but against the other strains used it was weaker. Furthermore, MT exhibited 5-10 times higher cytotoxic activities against tumour cell lines HCT-116, MCF-7 and K-562 than TR, but was less toxic than TR $\left(\mathrm{LD}_{50}\right.$ of MT was $375 \mathrm{mg} / \mathrm{kg}$, while $\mathrm{LD}_{50}$ for TR was $75 \mathrm{mg} / \mathrm{kg}$ ). Additionally, compounds MT and TR were studied in DNA binding tests. The quenching of its fluorescence on addition to DNA solution established

Correspondence to: Dr Alexander Popov, Department of Biotechnology, G.B. Elyakov Pacific Institute of Bioorganic Chemistry, Far Eastern Branch of The Russian Academy of Sciences, 159 Prospect 100-letiya Vladivostoku, Vladivostok 69022, Russia E-mail: popovam@piboc.dvo.ru

\section{${ }^{*}$ Contributed equally}

Key words: mostotrin, quinazoline alkaloids, tryptanthrin, natural product chemistry, synthetic derivatives of tryptanthrin, antitumour agents, antimicrobial agents
MT to be capable of binding to DNA. Its anti-tumour action in vivo on mice with the ascitic form of Ehrlich carcinoma was promising, particularly with joint application of MT and the antitumour drug doxorubicin. In this model, the survival and life span for the doxorubicin and 1 co-treatment group were significantly higher compared to doxorubicin treatment alone. The compound MT showed a lower immunosuppressive effect than TR at the early stages of inflammation induced in mice by LPS from E. coli (MT hardly inhibited the release of IL-1, IL-2, or INF- $\gamma$ ). These results demonstrated that MT is a perspective hit compound for drug development. In our opinion, further evaluation on the biological effects of MT and its synthetic analogues could lead to safer and more effective anti-tumour and anti-tuberculosis agents than TR itself. MT has also the prospect of application in combination with known anti-tumour drugs for the treatment of oncological diseases.

\section{Introduction}

Quinazoline alkaloid tryptanthrin (TR) is one of the most widespread and well known cytotoxic and antimicrobial agents (1), obtained for the first time more than 140 years ago by sublimation of natural indigo under reduced pressure. Although TR was obtained by this method and by oxidation of indigo long before its finding in different biological sources, it was later isolated, using a chromatographic separation technique, from extracts of numerous indigoid higher plants (genera Couroupita, Isatis, Polygonum, Strobilanthes and others), fungi (Candida lipolitica, Schizophyllum commune, Leucopaxillus cerealis) (1), marine bacteria (2) as well as yeasts of the genus Malassezia, known as a part of the normal skin flora (3).

Therapeutic application of tryptanthrin-containing topical preparations in Chinese folk medicine (4) confirmed its potent anti-inflammatory action as well as anti-tumour and 
antimicrobial activities, particularly against mycobacteria and pathogenic protozoa, including malaria plasmodia (5-8). A tryptanthrin-containing oral and topical preparation has been developed using chitosan as carrier of TR, known as 'Kourochitin'. It has been shown that this preparation has anti-inflammatory, antimicrobial, wound healing, anti-tumour, anti-allergic and other biological activities (9-12).

The peculiarities of TR biological action include an absence of membrane activity, ability to exhibit an immunosuppressive effect and an increase in intracellular ROS level (13). Oxidative stress induced by TR in various tumour cell lines is one of the assumed reasons for its cytotoxic activity and the ability to cause cell death via apoptosis mechanisms $(1,14)$. Interest in TR and its natural and synthetic derivatives was stimulated, not only by its promising biomedical properties, but also by its possibility of obtaining good yields using different synthetic methods; the coupling of isatin or its sodium salt with isatoic anhydride (1), oxidation of isatin (15), its treatment with $\mathrm{PCl}_{5}$ or $\mathrm{POCl}_{3}(16)$, and condensation of anthranilic acid with different aromatic derivatives (1) are examples of this.

At the same time, the main imperfections of TR and of the majority of its analogues and derivatives include very poor solubility in biological liquids, relatively high toxicity and an immunosuppressive effect when administered systemically. Based on this, we designed synthesis of new therapeutically promising, water-soluble and less toxic derivatives. The strategy of the study was to obtain a water-soluble analog of $\mathrm{TR}$, known as mostotrin (MT), closely related to its mother compound by its flat structure, in which the $\mathrm{CO}$ group has been replaced by an isosteric $\mathrm{C}=\mathrm{N}$ group. This modification led to significant changes of biological activities MT in comparison with TR, particularly in enhancing antitumor properties. Herein, we report the synthesis and biological properties MT, namely the antibacterial, cytotoxic and antitumour activity.

\section{Materials and methods}

Obtaining mostotrin from tryptanthrin. TR $(0.508 \mathrm{~g}, 2 \mathrm{mmol})$, produced by experimental plant of PIBOC (Russia) by oxidation of isatin, and $20 \mathrm{ml}$ of ice acetic acid, was placed in a two-neck flask equipped with a dropping funnel and reflux condenser and heated at $90^{\circ} \mathrm{C}$ over $1 \mathrm{~h}$. Subsequently, Girard reagent $\mathrm{T}(0.458 \mathrm{~g}, 2.7 \mathrm{mmol})$, in $4 \mathrm{ml}$ of ice acetic acid, was added dropwise for $10 \mathrm{~min}$ to the formed suspension. The reaction mixture was heated and stirred at the same temperature for $4 \mathrm{~h}$. The solvent was removed under reduced pressure from the obtained red-brown solution at $60^{\circ} \mathrm{C}$. The residue was treated with water $(15 \mathrm{ml})$, stirred and filtered. The resulting solution was concentrated on a rotary evaporator in a vacuum and, consequently, butanol was added in small portions as a defoamer. Ethanol $(20 \mathrm{ml})$ was added to the concentrate. After cooling at $5^{\circ} \mathrm{C}$ for $12 \mathrm{~h}$, the precipitate of the product MT was separated by filtration (yield 67\%), m.p. $>248^{\circ} \mathrm{C}$ (decomp.) and twice crystallised from ethanol. Its solubility was determined in experiments to obtain an aqueous solution of $200 \mathrm{mg} / \mathrm{ml}$ concentration using warm water (approximately $40^{\circ} \mathrm{C}$ ); the obtained solution was stable for at least 1 month without turbidity or sedimentation. For comparison, the mother compound (TR) was sparingly soluble. Approximately $39 \mathrm{mg}$ was separated by filtration and drying to a constant weight
(3 replicates) after boiling $40 \mathrm{mg}$ of TR in $400 \mathrm{ml}$ of water, corresponding to a solubility of $0.0025 \pm 0.0005 \mathrm{mg} / \mathrm{ml}$. This corresponds with information about its solubility, of $2.5 \mu \mathrm{g} / \mathrm{ml}$, from the company producing this preparation (Enzo-Life Science; tryptanthrin, inhibitor of prostaglandin and leukotriene synthesis; CAS 13220-57-0). Thus, MT was at least 5 orders of magnitude more soluble in water than its mother compound (TR).

${ }^{1} \mathrm{H}$ and ${ }^{13} \mathrm{C}$ NMR spectra were measured on Bruker Avance 700 and 400 spectrometers (Bruker Corporation) at 700 and $100 \mathrm{MHz}$, respectively, using $\mathrm{D}_{2} \mathrm{O}$ or DMSO-d6 as the solvent. Signals were assigned using a DEPT-135 pulse sequence. The ${ }^{1} \mathrm{H}$ NMR spectrum was $\left[700 \mathrm{MHz},\left(\mathrm{D}_{2} \mathrm{O}\right.\right.$, $\mathrm{d}_{6}$-acetone as exterior standard, $\left.\left.2.219 \mathrm{ppm}\right)\right]: 7.83 \mathrm{~d}(1 \mathrm{H}), 7.76 \mathrm{~d}$ $(1 \mathrm{H}), 7.66 \mathrm{t}(1 \mathrm{H}), 7.748 \mathrm{~m}(\mathrm{NH}), 7.45 \mathrm{t}(1 \mathrm{H}), 7.395 \mathrm{~d}(1 \mathrm{H}), 7.36 \mathrm{t}$ $(1 \mathrm{H}), 7.32 \mathrm{~d}(1 \mathrm{H}), 7.18 \mathrm{t}(1 \mathrm{H}), 4.645 \mathrm{~s}(2 \mathrm{H}), 3.495 \mathrm{~s}(9 \mathrm{H})$. The ${ }^{13} \mathrm{C}$ NMR spectrum was (DEPT, $\left.\left(\mathrm{CD}_{3}\right)_{2} \mathrm{SO}, 39.5 \mathrm{ppm}\right): 168.4$, 166.5, 157.7, 145.7, 145.5, 140.1, 135.3, 132.3, 129.3, 128.15, $126.9,126.85,122.2,121.95,121.3,117.6,116.4,62.0\left(\mathrm{CH}_{2}\right)$, $53.6\left(\mathrm{CH}_{3}\right)_{3}$.

The IR spectra were recorded in $\mathrm{KBr}$ on a Spectrum BX-II spectrometer (Perkin Elmer). IR spectrum (KBr): $3430(\mathrm{NH})$, $2925\left(\mathrm{CH}_{2}\right), 1691(\mathrm{C}=\mathrm{O}), 1632 \mathrm{~cm}^{-1}(\mathrm{C}=\mathrm{N})(\mathrm{SI})$.

Mass spectra were recorded using an Agilent 6510 Q-TOF apparatus (Agilent Technologies), with a sample concentration of $0.01 \mathrm{mg} / \mathrm{ml}$ in methanol. ESI HRMS, positive mode, $\mathrm{m} / \mathrm{z}: 362.1610$, calculated for cation $\mathrm{C}_{20} \mathrm{H}_{20} \mathrm{~N}_{5} \mathrm{O}_{2} 362.1612$; ESI HRMS/MS of 362.1611, positive mode, m/z: 260.0822 $\left(\mathrm{M}^{+}-\mathrm{HCl}-\mathrm{COCH}_{2}-\mathrm{N}\left(\mathrm{CH}_{3}\right)_{3}\right)(\mathrm{SI})$.

The samples were dissolved in $\mathrm{MeOH}(\mathrm{c} 0.001 \mathrm{mg} / \mathrm{ml})$ and Sorbfil Si gel plates $4.5 \times 6.0 \mathrm{~cm}, 5-17 \mu \mathrm{m}$ (Sorbpolimer) were used for thin-layer chromatography. Melting points were determined on melting point apparatus Leuca VM HB.

$X$-ray analysis of mostotrin. Analysis was carried out using a diffractometer, Bruker Kappa APEX2 (Bruker Corporation) (MoKa-radiation, graphite monochromator) at $173^{\circ} \mathrm{K}$. Data collection, editing and refinement of the unit cell parameters were carried out using APEX2 programs (Bruker Corporation) (17). Calculations on the definition and refinement of the structure were made using the SHELXTL/PC programmes, Georg-August Universitat Gottingen, Department of Structural Chemistry, Gottingen, Germany (18). Absorption of X-rays in the sample was taken into account by equivalent reflections. The structure was determined by the direct method and refined by the least square method in the anisotropic approximation of non-hydrogen atoms. Hydrogen atoms were placed in geometrically calculated positions and refined in the rider model to study their participation in the formation of intramolecular bonds. The CIF file, containing information concerning the structure of MT, was deposited in the CCDC, no. 1964205 .

Studies on binding MT and TR to DNA. Spectra for the studies concerned with binding to DNA were carried out in $10 \mu \mathrm{M}$ phosphate buffer $\left(\mathrm{pH} \mathrm{8.0)}, 100 \mathrm{mM} \mathrm{KCl}\right.$ solution at $22^{\circ} \mathrm{C}$. Calf thymus DNA (Sigma) (ctDNA) was used in experiments. Fluorescence spectra were recorded with Cary Eclipse Fluorescence Spectrophotometer (Agilent Technologies) for $10 \mu \mathrm{M}$ of compounds with increased DNA concentration. 
The excitation wavelength was $380 \mathrm{~nm}$, and emission was recorded in the range of 400-650 $\mathrm{nm}$. Circular dichroism spectra were recorded with a Jasco J715 spectropolarimeter (JASCO Corporation). DNA concentration was $100 \mu \mathrm{M}$ (base pairs), and concentrations of the studied compound were 10 and $50 \mu \mathrm{M}$ (19). Binding parameters were calculated from the dependence of fluorescence intensity on DNA concentration using the McGhee-von Hippel equation (20). The binding isotherm reflecting an anti-cooperative binding of MT to DNA was plotted in the Scatchard coordinates.

Antimicrobial action. Strains of microorganisms, including Escherichia coli ATCC 25922, Pseudomonas aeruginosa ATCC 27853, Bacillus cereus ATCC 10702, Candida parapsilosis ATCC 22019, Mycobacterium spp. R (fast growing nog9), were obtained from the museum of the Gause Institute of New Antibiotics, Moscow, Russia. Aqueous solutions of MT and DOX, or their solutions in PBS, as well as solutions of TR in DMSO (Sigma-Aldrich) were used in experiments. To reactivate after cryoconservation, test strains of microorganisms were seeded on agar nutrient medium as follows: Bacterial strains on CASO-Agar (Sifin), and Candida parapsilosis with a titre of $2.5 \times 10^{3} \mathrm{CFU} / \mathrm{ml}$ on RPMI-1640 medium (PanEco) with the addition of $0.2 \%$ glucose or on Saburo (Sigma-Aldrich). The bacterial strains were cultivated for 18-20 h, with the exception of Mycobacterium spp., which was cultivated for 3-5 days, and Candida parapsilosis which was cultivated for $48 \mathrm{~h}$ at $35 \pm 2{ }^{\circ} \mathrm{C}$. After cultivation, the biomasses of microorganisms were diluted in a physiological solution (Sigma-Aldrich) to a turbidity of 0.5 units, according to the McFarland turbidity standard, which was measured on a McFarland Densitometer (Biosan). Subsequently, $10 \mu \mathrm{l}$ portions of the studied compounds were added to the wells with microorganisms at the concentration range of $0.06-128 \mu \mathrm{g} / \mathrm{ml}$. The plates with the tested strains were incubated in a normal atmosphere at a temperature of $35 \pm 2^{\circ} \mathrm{C}$ for $16-24 \mathrm{~h}$ for bacterial cultures (in the case of Mycobacterium spp. $\mathrm{R}=96 \mathrm{~h}$ ), and 24-48 h for Candida spp. The growth rate of microorganisms in each well was measured by the turbidity/absorption of the cell inoculum using a microplate reader at a wavelength between 405 and $530 \mathrm{~nm}$. Antimicrobial activities of the tested compounds were determined as the minimum inhibitory concentration (MIC). The analysis was carried out in accordance with the recommendations of Russian GOST R ISO 20776-1-2010 and GOST R ISO 16256-2015 rules and the standard protocol described within.

Cytotoxic activity against tumour cells. The K562 human leukaemia, HCT116 colon carcinoma, B16-F0 murine melanoma, MCF-7 human breast adenocarcinoma and MDA-MB-231 human breast cancer cell lines were purchased from the American Type Culture Collection (ATCC). The reagents were purchased from Sigma-Aldrich, unless specified otherwise.

An aqueous solution of MT or its solution in PBS, as well as solutions of TR and doxorubicin (DOX) in DMSO, were used in the experiments. Cultures of the corresponding cells in the logarithmic growth phase were placed in a 96-well plate (Nalge NUNC International) at $5 \times 10^{3}$ cells per well in $190 \mu 1$ of Eagle's culture medium (PanEco) and RPMI-1640 medium (PanEco), with the addition of 5-10\% fetal bovine serum (HyClone), $2 \mathrm{mM}$ L-glutamine, $100 \mathrm{U} / \mathrm{ml}$ penicillin and $100 \mu \mathrm{g} / \mathrm{ml}$ streptomycin and incubated for $24 \mathrm{~h}$ at $37^{\circ} \mathrm{C}, 5 \% \mathrm{CO}_{2}$. The cells were processed with $10 \mu \mathrm{l}$ of each solution of the studied compounds, prepared by successive double dilutions, added in a range of final concentrations from 0.1 to $50 \mu \mathrm{M}$ (total 10 concentrations: $0.1 ; 0.2 ; 0.4 ; 0.8 ; 1.6 ; 3.2 ; 6 ; 12 ; 25$ and $50 \mu \mathrm{M})$ and with $0.1 \%$ DMSO (vehicle control). Then, the treated cells were incubated for $72 \mathrm{~h}$ (each concentration was studied with three replications). At the end of the incubation, $10 \mu \mathrm{l}$ of an aqueous solution of 3-(4,5-dimethyl-thiazol-2-yl)-2,5-diphenyl tetrazolium bromide (MTT, PanEco; $5 \mathrm{mg} / \mathrm{ml}$ ) was introduced into the wells. After staining, the culture medium was removed, the cells were suspended in $100 \mu \mathrm{l}$ of DMSO, and the optical density of the solutions was measured on a microplate ELx800 photometer (BioTek) at a wavelength of $570 \mathrm{~nm}$. The number of living cells in each sample $(\mathrm{N}, \%)$ was calculated as a percentage of the control using the formula $\mathrm{N}=(\mathrm{IE} / \mathrm{IK})$ $\mathrm{x} 100 \%$, where IE is the optical density in each experimental well and IK is the optical density in the control wells (samples not treated with compound 1 or 2 , the values $\mathrm{N}$ of which are taken as $100 \%$ ). The cytotoxic effect of the compounds was characterised by the concentration of half-maximal inhibition $\left(\mathrm{IC}_{50}\right)$, which was calculated based on the obtained values of $\mathrm{N}$.

Animals. Animal procedures were performed using female CD-1 (total 145 animals) or BALB/C (total 28 animals) albino mice, weighing $25 \pm 2 \mathrm{~g}, 8-10$ weeks of age, originally obtained from the vivarium of the Institute of Bioorganic Chemistry, Pushchino, Russia. The mice were housed in standard animal facility in cages with an ambient temperature of $22 \pm 2^{\circ} \mathrm{C}$, a controlled humidity of $50 \%$ and a 12 -h light/dark cycle and were provided with free access to standard food and water.

Toxicity. Toxicity assessment was performed using CD-1 albino mice, weighing $25 \pm 2 \mathrm{~g}$. MT was administered once intraperitoneally in doses of 500, 250, 125 and $50 \mathrm{mg} / \mathrm{kg} / \mathrm{mice}$ (5 mice in each group). Within $24 \mathrm{~h}$ after injection, mortality and changes in basic physiological parameters, such as body temperature, breathing frequency, wool characteristics, physical activity (motility, coordination and speed of movement), behavioural responses (excitation or inhibition, eating and drinking behaviours, grooming), were visually registered in each group of animals. $\mathrm{LD}_{50}$ values were calculated $24 \mathrm{~h}$ after administration using the formula:

$$
\mathrm{LD}_{50}=\mathrm{LD}_{100}-\sum \mathrm{Zd} / \mathrm{n}
$$

where, $\mathrm{LD}_{100}$ is the maximum dose that causes the death of all animals in the group, $\mathrm{Z}$ is the arithmetic average of the number of animals in which a mortality is noted under the influence of two adjacent doses, $d$ is the interval between two adjacent doses, and $n$ is the number of animals in each group (21).

Ethics approval. The animal study was performed in accordance with the European Convention for the Protection of Vertebrate Animals, Directives 86/609/EEC (Council of Europe European Convention for the Protection of Vertebrate 
Animals used for Experimental and Other Scientific Purposes. Strasbourg: 1986, Accessed August 28, 2018) 18.III.1986. Council of Europe, ETS No. 123, European Convention for the humane methods for the animal welfare and maintenance [Directive 2010/63/EU on the protection of animals used for scientific purposes EN. Official Journal of the European Union, L 276/33-276/79 (20.10.2010)], the National Standard of the Russian Federation R 53434-2009 'Good Laboratory Practice' (National state standard GOST P 53434-2009 the Russian Federation standard 'The principles of Good Laboratory Practice' approved and put into effect by the Order of the Federal Agency for Technical Regulation and Metrology of December 2, 2009, No 544) and approved by Ethic Committee of Animal Experimentation of G.B Elyakov Pacific Institute of Bioorganic Chemistry of the Russian Academy of Science.

Murine model of ascite Ehrlich's adenocarcinoma. Ascitic Ehrlich carcinoma cells (EACCs) were maintained in the vivarium of PIBOC (Pacific Institute of Bioorganic Chemistry) using CD-1 albino mice by serial intraperitoneal (i.p.) passages with 7-10 day intervals. The mice were euthanised 7 days after inoculation, and the ascitic fluid was collected under aseptic conditions from tumour-bearing mice by needle aspiration from the peritoneal cavity. EACCs were obtained after washing three times with normal saline, followed by centrifugation (Eppendorf Centrifuge 5804) at 1,500 x $\mathrm{g}$ for $10 \mathrm{~min}$ at $24^{\circ} \mathrm{C}$. Tumour cell counts were carried out using the trypan blue dye exclusion method. Cell viability was examined microscopically. For the study on anti-tumour activity, a suspension of these tumour cells $\left(3 \times 10^{6}\right.$ cells/mouse) in $0.5 \mathrm{ml}$ of $1 \%$ phosphate-buffered saline (PBS) (Sigma-Aldrich) was injected i.p. into CD-1 mice. One day after tumour inoculation, treatment was started with the studied compounds. The compounds and saline (for negative control) were injected i.p. as $0.5 \mathrm{ml}$ aqueous solutions over 5 days (one injection per day). MT was used both in monotherapy at doses of $2.5,5,10$, 25 and $50 \mathrm{mg} / \mathrm{kg}$ and in combination (with 5 or $10 \mathrm{mg} / \mathrm{kg}$ of $\mathrm{MT}+0.25 \mathrm{mg} / \mathrm{kg}$ antitumour drug, Doxorubicin-Teva, (DOX) (Pharmachemie). The animals were divided into the following groups, $n=9$ per gropu: i) Contr(-), negative control; ii) DOX, $0.25 \mathrm{mg} / \mathrm{kg}$; iii) MT, $2.5 \mathrm{mg} / \mathrm{kg}$; iv) MT, $5 \mathrm{mg} / \mathrm{kg}$; v) MT, $10 \mathrm{mg} / \mathrm{kg}$; vi) MT, $25 \mathrm{mg} / \mathrm{kg}$; vii) MT, $50 \mathrm{mg} / \mathrm{kg}$; viii) Dox $0.25 \mathrm{mg} / \mathrm{kg}+\mathrm{MT}, 5 \mathrm{mg} / \mathrm{kg}$; ix) DOX $0.25 \mathrm{mg} / \mathrm{kg}+\mathrm{MT}$ $10 \mathrm{mg} / \mathrm{kg}$.

Mean survival time (MST) and the percentage of increase in life span (\% ILS) were calculated using the formulae: MST=Survival time (days) of each mouse in a group/Total number of mice and \% ILS=MST of treated mice/MST of control group $\mathrm{x} 100 \%$.

Murine model of solid Ehrlich's adenocarcinoma. EACCs were obtained as described in the previous section. Experiments were performed using $\mathrm{BALB} / \mathrm{C}$ albino mice. Mice were inoculated with $0.2 \mathrm{ml}$ containing $1.5 \times 10^{6}$ viable EACCs in the right hind limb (thigh) subcutaneously. The animals were randomised and divided into 4 groups $(n=7)$ : i) Cont(-), negative control; ii) DOX, $0.25 \mathrm{mg} / \mathrm{kg}$; iii) MT, $10 \mathrm{mg} / \mathrm{kg}$; iv) DOX, $0.25 \mathrm{mg} / \mathrm{kg}+\mathrm{MT}, 10 \mathrm{mg} / \mathrm{kg}$. The treatment started when the primary tumour reached a size of $57-60 \mathrm{~mm}^{3}$. All tested remedies and saline (for negative control) were injected i.p. as
$0.5 \mathrm{ml}$ portions of aqueous solutions for 5 days (one injection a day). Tumour volume was measured from the 10th day of tumour induction, and then every 4 days for a period of 17 days. Tumour growth was assessed by measuring the volume of the solid tumour using a digital calliper, and was calculated using the formula:

$$
\mathrm{V}=\pi / 6 \times \mathrm{L} \times \mathrm{W} \times \mathrm{H}
$$

where $\mathrm{V}$, tumour volume; L, tumour length; W, tumour width; $\mathrm{H}$, tumour height.

Evaluation of the chemotherapeutic efficacy of the tested remedies was carried out by inhibition tumour growth (TGI, \%) in the experimental groups. TGI was calculated as described in (22) using the formula:

$$
\mathrm{TGI}=(1-\mathrm{Ve} / \mathrm{Vc}) \times 100
$$

where, $\mathrm{Ve}$ and $\mathrm{Vc}$ represent the median tumour volume in experimental and control groups, respectively. On the termination day (22nd day of tumour induction) experimental animals were euthanised by cervical dislocation under ether anaesthesia, and the tumour mass was removed for visual assessment of the tumour.

Anti-inflammatory action. Lipopolysaccharide (LPS) from the bacterium E. coli (Sigma-Aldrich), at the dose of $0.1 \mathrm{mg} / \mathrm{kg}$, was used for simulation of early stages of system inflammation in female CD-1 mice. A matching volume of i.p.-injected PBS was used as a vehicle control. The positive control was provided by application of Dexamethasone, a corticosteroid anti-inflammatory drug, injected i.p. at a dose of $10 \mathrm{mg} / \mathrm{kg}$ $1.5 \mathrm{~h}$ after LPS application. All the mice were divided into 5 groups (n=7): i) Cont(in), intact animals; ii) Cont(-), animals treated only with LPS (negative control); iii) Cont(+), animals treated with LPS and Dexamethasone $1.5 \mathrm{~h}$ later, injected i.p. at a dose of $10 \mathrm{mg} / \mathrm{kg}$ (positive control); iv) MT, animals treated with LPS and $1.5 \mathrm{~h}$ later with MT injected i.p. at a dose of $10 \mathrm{mg} / \mathrm{kg}$; v) TR, treated with LPS and $1.5 \mathrm{~h}$ later with TR injected i.p. at a dose of $10 \mathrm{mg} / \mathrm{kg}$. Levels of cytokines (INF- $\gamma$, IL-1 and IL-2) as indicators of system inflammation, were determined in the plasma of mice by immunoassay (BD Bioscience OptEIA). Animals were terminally anaesthetised with sodium pentobarbital (40 mg per mouse i.p., Euthatal, Merial Animal Health). The thoracic cavity was opened, and blood collected in heparinised tubes directly from the right atrium of the heart. This whole blood was centrifuged at $1.5 \mathrm{x} \mathrm{g}$ for $15 \mathrm{~min}$ at $24^{\circ} \mathrm{C}$ to remove cells; the plasma was then aliquoted and stored at $-20^{\circ} \mathrm{C}$. These samples were diluted appropriately and then analysed for INF- $\gamma$, IL-1 and IL-2.

Statistical analysis. Statistical analyses were performed using GraphPad Prism software v.5.01 (GraphPad Prism Software Inc.) and MS Excel 2013 (Microsoft Corporation). The data for all in vitro and in vivo assays are presented as mean \pm SEM (standard error of the mean). Statistical analysis among various groups was conducted by a one-way analysis of variance with Tukey's post hoc test. Statistical analysis for the survival curves in the animal treatment study was carried out using the 
A

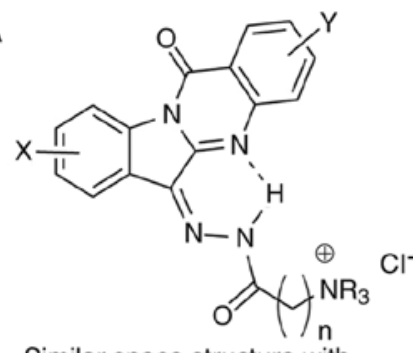

Similar space structure with original molecules

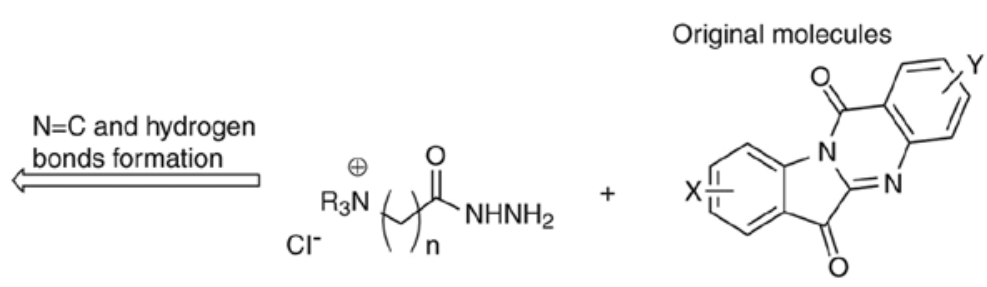

$\mathrm{X}, \mathrm{Y}$ - different substituents such as $\mathrm{H}, \mathrm{CH}_{3}, \mathrm{Br}$ $\mathrm{R}=\mathrm{CH}_{3}$ or Alkyl

B

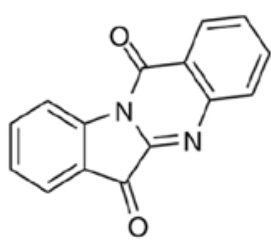

TR

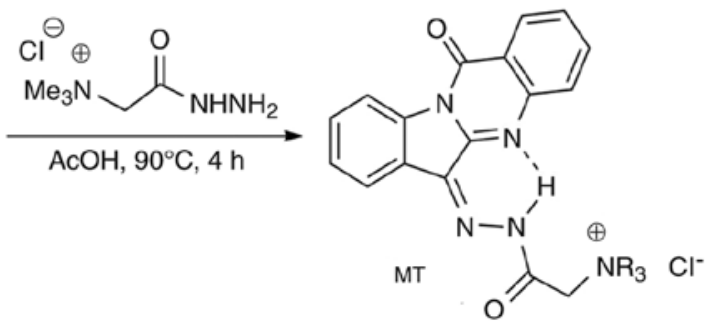

Figure 1. Syntheses of water-soluble derivatives of TR and the synthetic path to the compound MT. (A) Outline of water-soluble derivatives of tryptanthrin. (B) Synthesis of mostotrin: N,N,N-Trimethyl-2-oxo-2-[2-(12-oxoindolo[2,1b]-quinazoline-6(12H-iliden)-hydrazinyl]-ethyl ammonium chloride.

log-rank test (Mantel-Cox test). Statistically significant differences were considered if $\mathrm{P}<0.05$. In the antimicrobial action test, the MICs were determined from independent triplicate assays and were based on a serial 2-fold plus or minus system; to be considered valid, MIC determinations for each of the 3 replicates had to be within plus or minus 1 dilution of each other. If necessary, additional replicates were run until 3 replicates were obtained within these limits.

\section{Results}

Chemical synthesis and X-ray analysis. In order to improve the physicochemical properties and biological activity of TR, we performed chemical modifications of its structure. In particular, the reaction of TR and/or its derivatives was used with hydrazides of acids, which bear a positive charged fragment remote from the hydrazide group. Fig. 1A and B describe the strategy of syntheses of water-soluble derivatives of TR and the synthetic path to the compound MT, respectively. It was expected that the product would contain a nearly planar arrangement, similar to TR itself (23) due to an intramolecular hydrogen bond between the $\mathrm{NH}$ group in the side chain and the nitrogen atom in the core moiety (Fig. 1). Commercially available Girard reagent T, 1-trimethylammonium-3-hydrazinylpropan-2-one chloride, was determined to be suitable for this synthesis. Compound MT was synthesised by heating TR and Girard reagent in ice acetic acid (Fig. 1B).

The conditions of synthesis, as well as the NMR, MS and IR spectroscopic data of MT used to establish its structure, are described in the experimental section. These spectra are given in Figs. S1-4. The molecular structure of MT was also confirmed by single crystal X-ray analysis (Table SI) and the results are shown in Fig. 2. The crystalline molecular structure revealed the elemental unit to consist of twice repeated couples of oppositely oriented molecules of MT, four chloride ions and four water molecules (Fig. S5). The positions of hydrogen atoms were determined from the difference in electron density and were not specified. The atom, designated as H1 in Fig. 2, participates in the formation of intramolecular hydrogen bonds in 1 .

X-ray analysis showed that compound MT, when compared with that of the initial compound TR, has an additional six-membered pseudo-cycle, with five covalent and one hydrogen bonds (Fig. 2, Table SII).

The interatomic distance of the abovementioned intramolecular bond (Table SII) emphasised this hydrogen bond to be strong because its length $(1.75 \AA)$ was insignificantly more than the sum of Van-der-Waals radiuses of nitrogen and hydrogen atoms $(1.55+1.09 \AA)$. The plane obtained by our compound is as flat as TR (23) and has a similar electron density distribution, caused by the replacement of one carbonyl group for an isosteric $\mathrm{C}=\mathrm{N}$ group.

Antimicrobial action. Parent TR and its derivatives showed a broad-spectrum of antimicrobial and antifungal activities (1). To evaluate the antimicrobial potential of the newly synthesised MT, we compared the antimicrobial activities of the compounds MT and TR against gram-negative and gram-positive bacteria, including Mycobacterium spp., and the fungus Candida parapsilosis (Table I).

The obtained MIC values against Bacillus cereus ATCC 10702 and Mycobacterium spp. showed a potent antimycobacterial action of MT and TR, but no significant differences were revealed between the compounds. The antifungal activities of both MT and TR against $C$. parapsilosis were rather moderate. However, MT, in contrast with TR, is less active in relation to the majority of other bacteria and the fungus. Therefore, it should be noted that both MT and TR had high antibacterial activity against the drug-resistant tuberculosis bacteria Mycobacterium spp.

Cytotoxic activities against tumour cells. In numerous earlier studies it was shown that TR itself, as well as some 
Table I. Experimental values of the minimum inhibitory concentration of MT and RT in relation to the pathogenic strains of microorganisms.

\begin{tabular}{lrr}
\hline & \multicolumn{2}{c}{ MIC $(\mu \mathrm{g} / \mathrm{ml})$} \\
\cline { 2 - 3 } Test microorganisms & \multicolumn{1}{c}{ MT } & TR \\
\hline Staphylococcus. aureus ATCC 29213 & 64 & 32 \\
Staphylococcus. aureus (MRSA) 88 & 128 & 32 \\
Enterococcus faecalis (VRE) 583 & 128 & 64 \\
Bacillus cereus ATCC 10702 & 8 & 8 \\
Escherichia coli ATCC 25922 & $>128$ & 8 \\
Pseudomonas aeruginosa ATCC 27853 & $>128$ & $>128$ \\
Mycobacterium spp. & 2 & 2 \\
Candida parapsilosis ATCC 22019 & 128 & 128 \\
\hline
\end{tabular}

MT, mostotrin; TR, tryptanthrin; MIC, minimum inhibitory concentration of three experiments.

of its derivatives and/or analogues, demonstrates cytotoxic action against various lines of human and animal tumour cells in vitro (1,24-26). In continuation of our search for more active and available cytotoxic compounds of this structural family (9), we evaluated the cytotoxic effect of the synthesised compound MT against the cell lines given in Table II. A wide range of tumour cell lines of various tissue origins was chosen for the MTT test. This allowed the rating of the cytotoxic activity of the new derivative MT in comparison with its paternal alkaloid TR but also the selection of cell lines sensitive to the new cytotoxic agent.

DOX, well-established against various types of cancer, was used as a positive control. It was demonstrated that MT showed higher activity, when compared with TR, against HCT-116, K-562 and MCF-7 tumour cell lines. By contrast, TR did not show activity against these cell lines at the investigated range of concentrations (50 $\mu \mathrm{M}$ and below) but was more active against the MDA-MB-231 cell line. MT and TR did not show activity in relation to B16-F0.

In this way, compound MT was 5- to 40-fold more active against human tumour cells in comparison with TR, with the exception of MDA-MB-231 cells. Interestingly, compound MT exhibited the highest cytotoxic activity to the chronic myelogenous leukaemia cell line ( $\mathrm{IC}_{50}, \mu \mathrm{M}=1.0 \pm 0.1$ ) (Table II). The high sensitivity of K-562 cells to the cytotoxic effect of MT may be associated with the biochemical proliferation features of these undifferentiated progenitor cells (27) and the presence of selective molecular targets for MT. Thus, the higher antiproliferative activity of MT against the majority of tested tumour cell lines and the much lower toxicity, in comparison with TR, suggested a probable augmentation of MT antitumour potential in vivo.

Studies on binding of MT and TR to DNA. To connect the shown cytotoxic activity with the physicochemical properties of MT, its chemical structure was taken into consideration. The planar structure of MT suggests this compound was able to interact with DNA and/or intercalate

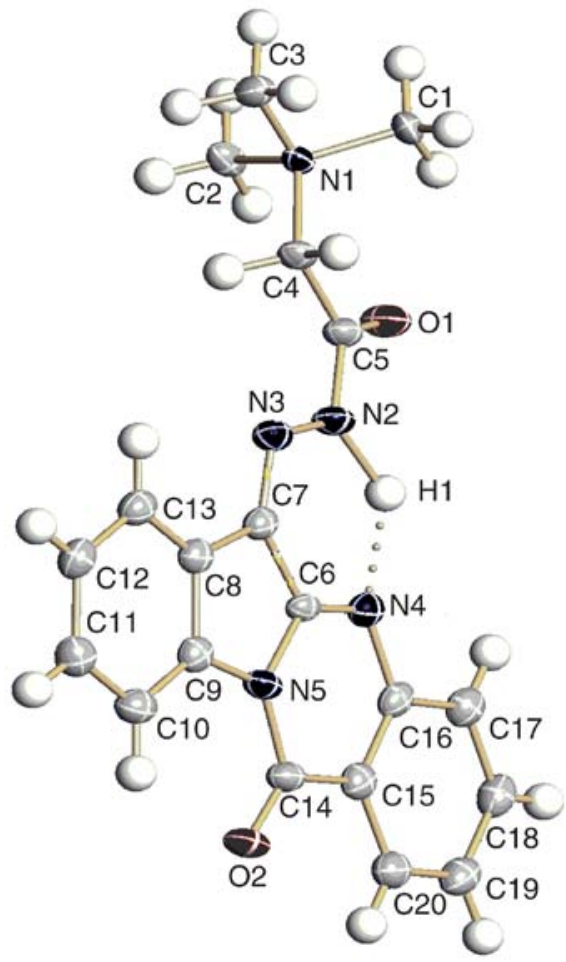

Figure 2. Molecular structures of MT.

between DNA nucleotides in double-stranded DNA, and this may be connected with the mechanism of its biological action as has been shown for some other clinically established drugs (28). In order to determine whether the compounds MT and/or TR interact with ctDNA, a titration of the studied compounds with different concentrations of DNA was performed. In this experiment, it was shown that both MT and TR have intrinsic fluorescence, with a maximum near $500 \mathrm{~nm}$. Using changes in fluorescence as a convenient method to indicate the formation of DNA complexes with the studied compounds, we initially established that the fluorescence of MT was markedly stronger when compared with TR. Apparently, the increase in fluorescence of MT is due to the replacement of a ketone oxygen in the precursor TR by nitrogen, linked to the side chain of MT. Notably, TR in contrast to MT, did not change in fluorescence in our experiments when DNA was added to its solution. Fluorescence quenching of the studied compound MT in this experiment showed its capability to be bound with DNA (Fig. 3A-C).

Binding parameters can be calculated from the dependence of fluorescence intensity on DNA concentration. The binding isotherm was plotted in the Scatchard coordinates (Fig. 3D). The isotherm reflects an anti-cooperative binding of MT to DNA. The approximation of the McGhee-von Hippel equation allowed us to determine the binding parameters. Approximately 5 base pairs on DNA were occupied by MT. The binding constant for MT was approximately $3 \times 10^{5} \mathrm{M}^{-1}$. At the same time, it should be noted that changes in the fluorescence intensities and spectra were not observed in experiments with TR. Therefore, the latter seems to have a much weaker interaction with DNA under the given conditions. 
Table II. Antiproliferative activities of MT and TR in comparison with the antitumor drug doxorubicin.

\begin{tabular}{lccccc}
\hline & \multicolumn{5}{c}{$\mathrm{IC}_{50}, \mu \mathrm{M}$} \\
\cline { 2 - 5 } Test compounds & HCT-116 & MCF-7 & B16-F0 & K-562 & MDA-MB-231 \\
\hline MT & $5.0 \pm 0.4^{\mathrm{b}}$ & $11.0 \pm 0.9^{\mathrm{a}}$ & $>50$ & $1.0 \pm 0.1^{\mathrm{b}}$ & $46.0 \pm 2.7$ \\
TR & $>50$ & $>50$ & $48.3 \pm 3.9$ & $42.4 \pm 3.2$ & $21.2 \pm 1.7$ \\
DOX & $0.11 \pm 0.02$ & $0.61 \pm 0.05$ & $0.55 \pm 0.05$ & $0.10 \pm 0.01$ & $0.52 \pm 0.05$ \\
\hline
\end{tabular}

MT, mostotrin; TR, tryptanthrin; DOX, doxorubicin; HCT-116, human colon carcinoma cell line; MCF-7, human breast adenocarcinoma cell line; B16-F0, murine melanoma cell line; K-562, human leukemia cell line; MDA-MB-231, human breast cancer. IC $_{50}, 50 \%$ : Growth inhibitory concentration. Results are presented as mean $\pm \mathrm{SEM}, \mathrm{n}=3 .{ }^{\mathrm{a}} \mathrm{P}<0.05,{ }^{\mathrm{b}} \mathrm{P}<0.01 \mathrm{MT}$ vs. TR (Tukey's test), the effect of MT and TR is incomparable with a DOX.
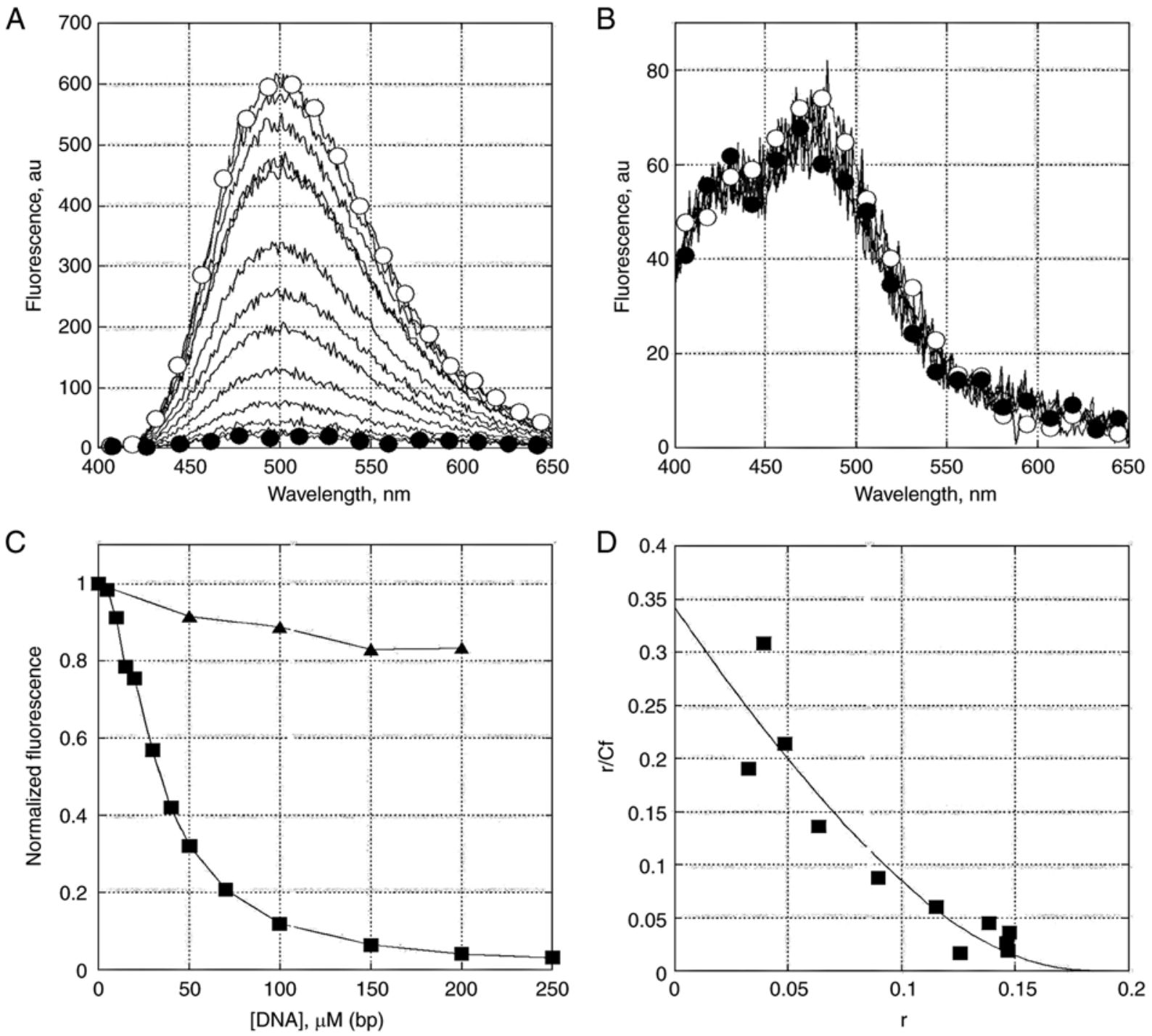

Figure 3. Fluorescence reflects the ctDNA binding by TR and MT. Fluorescence spectra of (A) TR and (B) MT are changed upon increases in DNA concentration; open circles, free compounds; filled circles, presence of $200 \mu \mathrm{M}$ (base pairs) DNA. (C) Dependence of relative fluorescence intensity at $500 \mathrm{~nm}$ on DNA concentration; TR, triangles; MT, squares. (D) Binding isotherm of MT to DNA, solid line is approximation with McGhee-von Hippel equation with binding parameters $\mathrm{L}=4.9 \pm 0.4$ base pairs, $\mathrm{Kb}=3.4 \pm 0.4 \times 10^{5} \mathrm{M}^{-1}$.

Circular dichroism spectra changed upon binding of MT. In order to clarify the conformation of the complex formed by MT and DNA, circular dichroism (CD) spectra of DNA
(Fig. 4A) and the studied compound in complexes with DNA (Fig. 4B) were obtained. A change of CD spectrum in the region of DNA absorbance (Fig. 4A) was associated with 

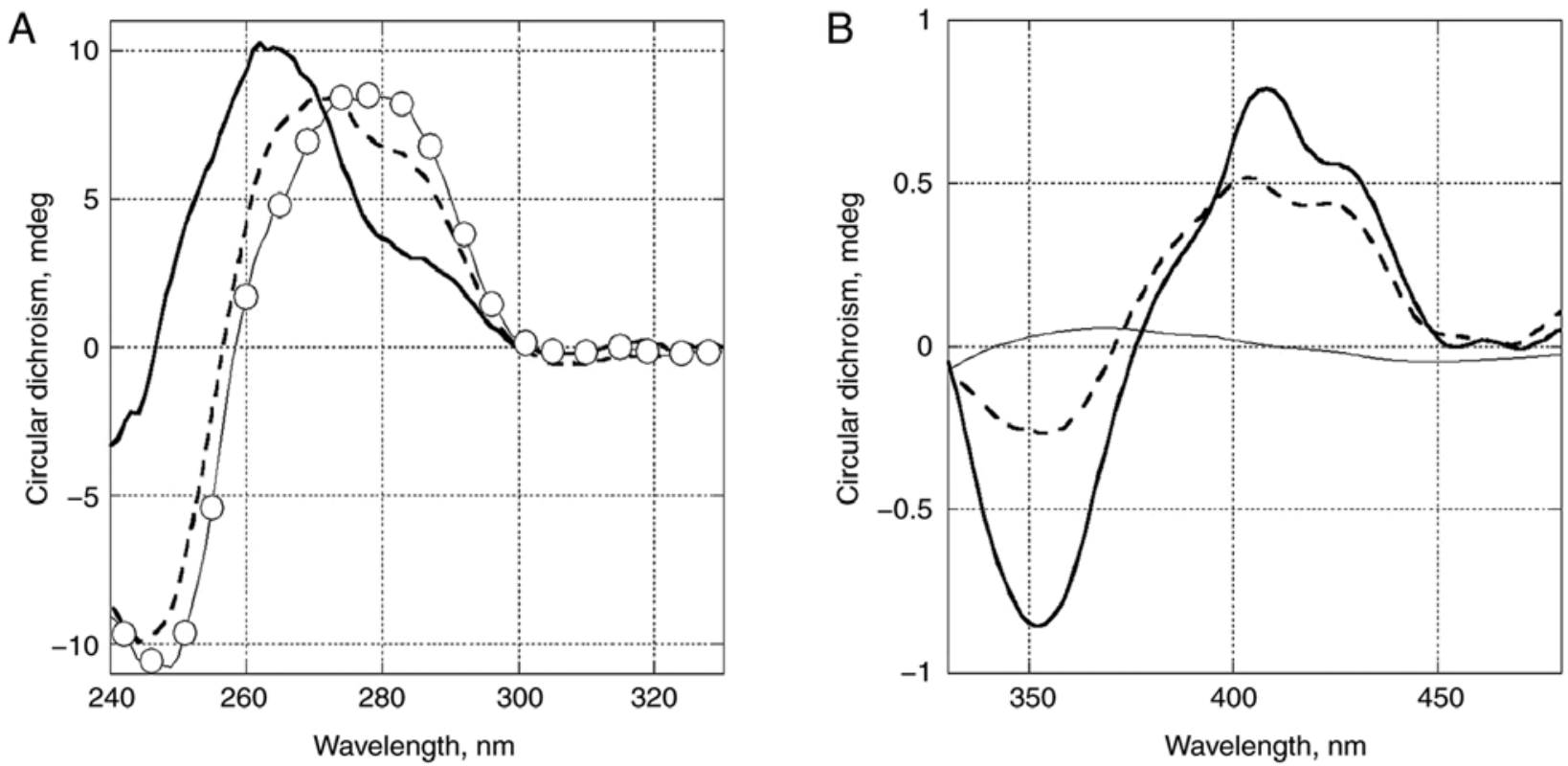

Figure 4. Circular dichroism (CD) spectra changed upon binding of MT. Changes of CD in ctDNA absorbance region. (A) CD spectra of MT induced by DNA binding. (B) DNA concentration was $100 \mu \mathrm{M}$ (base pairs), concentration of MT was $10 \mu \mathrm{M}$ (dashed line) and $50 \mu \mathrm{M}$ (solid line). CD spectrum of DNA in absence of compound plotted with solid line marked with open circles.

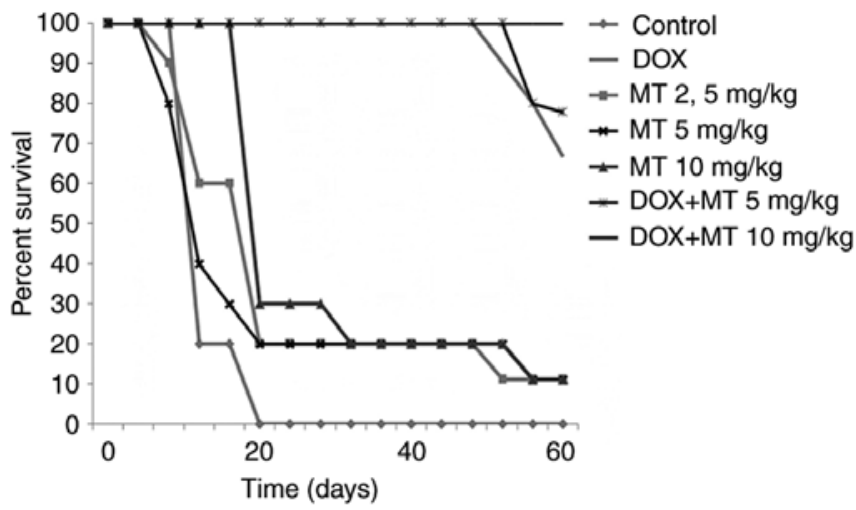

Figure 5. Boosting effect of combinatorial treatment with DOX and different doses of MT. Survival plot of tumour-inoculated animals treated with DOX or different doses of MT alone, and the DOX-MT combination. Statistical analysis for the survival curves was carried out using the log-rank test. $\mathrm{P}<0.05$, calculated in pairwise comparisons, was considered statistically significant.

conformational changes in DNA. It is of interest that the spectrum became similar to that of DNA A-form (positive band of DNA at $280 \mathrm{~nm}$ shifted to $260 \mathrm{~nm}$ ).

These changes could also be caused by an induced CD spectrum of the ligand. The long wavelength absorbance in the CD spectrum reflected the ligand binding mode (Fig. 4B). The positive band at low DNA occupancy (ratio of concentrations of DNA to MT is 10:1) demonstrated a groove binding was more likely than intercalation. A higher DNA occupancy led to the increased amplitude of a negative band near $350 \mathrm{~nm}$, which apparently came from a close interaction of bonded nearby molecules. CD spectrum changes by TR at the same conditions were not detected.

Thus, the binding of MT with DNA, in contrast with the initial compound TR used for its synthesis, was confirmed in our experiments. Further attention should be paid to this specific binding in future studies on the molecular mechanisms of action of MT.

Toxicity. Following these in vitro results, the examination of general toxicity in vivo, of the novel compound MT in comparison with TR, was carried out. The acute toxicity of MT was evaluated at doses from 50 to $500 \mathrm{mg} / \mathrm{kg} / \mathrm{mice}$ (a single injection) via i.p. administration. A slight toxic effect of MT at doses from 125 to $250 \mathrm{mg} / \mathrm{kg}$ was observed during the first 15-60 min after administration, with the following external signs of intoxication: Decreased body temperature, shortness of breath, decreased mobility and general physical activity. These occurred without subsequent mortality. In these experimental groups, mortality was not detected and after $24 \mathrm{~h}$, the animals showed a full recovery. However, at the dose of $500 \mathrm{mg} / \mathrm{kg}$, all the animals in the experimental group died within 30-60 min, which is the reason for not using higher doses. The calculation established the $\mathrm{LD}_{50}$ of MT to be $375 \mathrm{mg} / \mathrm{kg}$, making it possible to classify this compound as moderately toxic, according to the Hodge and Sterner toxicity scale. The $\mathrm{LD}_{50}$ of TR, as previously determined by us in the same animals, was determined to be $75 \mathrm{mg} / \mathrm{kg}$. Therefore, we concluded that MT is approximately 5-fold less toxic than TR (unpublished data).

Antitumour activity in vivo using a murine model of the ascitic form of Ehrlich adenocarcinoma. In our experiments, DOX was used as a positive control and along with compound MT for combinational treatment. The anti-tumour activity of the studied compound MT was dose-dependent and its overall activity was less than the activity of DOX. At doses of 50 and $25 \mathrm{mg} / \mathrm{kg}$, this compound provided survival rates of 37.5 and $25 \%$, respectively (data not shown). Active doses, which provided both survival and life expectancy, ranged from 2.5 to 
Table III. Evaluation of antitumor activity at treatment with DOX, MT and combinations of DOX and MT.

\begin{tabular}{lccc}
\hline Group & Average life expectancy, days & Longer life expectancy, $\%$ & Survival, $\%$ \\
\hline Control(-) & $17 \pm 0.17$ & - & 0 \\
DOX $(0.25 \mathrm{mg} / \mathrm{kg})$ & $57.55 \pm 0.2^{\mathrm{a}}$ & $338 \pm 0.5$ & 67 \\
MT $(2.5 \mathrm{mg} / \mathrm{kg})$ & $26 \pm 0.45$ & $152.9 \pm 1.07$ & 10 \\
MT $(5 \mathrm{mg} / \mathrm{kg})$ & $25.7 \pm 0.47$ & $151.2 \pm 1.11$ & $171.2 \pm 1.06$ \\
MT $(10 \mathrm{mg} / \mathrm{kg})$ & $29.1 \pm 0.45$ & $346.5 \pm 0.4$ & 10 \\
DOX+MT $(0.25+5 \mathrm{mg} / \mathrm{kg})$ & $58.9 \pm 0.16^{\mathrm{a}}$ & $352.9 \pm 0^{\mathrm{b}}$ & 78 \\
DOX+MT $(0.25+10 \mathrm{mg} / \mathrm{kg})$ & $60 \pm 0^{\mathrm{a}}$ & 100 \\
\hline
\end{tabular}

Control(-), negative control (without treatment); DOX, doxorubicin treatment; MT, mostotrin treatment; DOX+MT, joint administration of doxorubicin and mostotrin. Results are presented as mean \pm SEM, $n=9$ for each group, ${ }^{a} \mathrm{P}<0.01$ vs. negative control group; ${ }^{\text {b }} \mathrm{P}<0.05$. $\mathrm{DOX}$ group vs. MT and DOX+MT 5-10 mg/kg groups (Tukey's test).

$10 \mathrm{mg} / \mathrm{kg}$, with maximum effects at $10 \mathrm{mg} / \mathrm{kg}$. The obtained results are given in the Table III and Fig. 5. It should be noted that joint application of MT+DOX, at doses of $0.25+5 \mathrm{mg} / \mathrm{kg}$, resulted in $78 \%$ of survival on the 60 th day, while increasing the dose of MT in this combination to $10 \mathrm{mg} / \mathrm{kg}$ provided $100 \%$ survival of mice, in contrast with the use of DOX alone. Thus, an enhancement of the anti-tumour action of DOX by MT was clearly established (Table III).

Moreover, the examination of surviving animals treated with DOX revealed more significant signs of secondary cancer development in comparison with animals treated with a combination of MT and DOX. In fact, tumours were observed in $70 \%$ of the surviving animals treated by DOX, but only in $10 \%$ of those treated by the combination DOX+MT (Table SIII).

Anti-tumour activity in vivo using the murine model of solid Ehrlich's adenocarcinoma. In this experiment, MT treatment hardly changed the tumour size, whereas treatment with DOX alone led to some inhibition of the tumour growth. In the DOX and MT co-treatment group, chemotherapeutic efficacy was higher. On the 22nd day of the experiment, tumour size was markedly decreased and tumour growth inhibition (TGI) was slightly $>20 \%$ (Table SIV, Fig. S5). Consequently, solid Ehrlich's adenocarcinoma is less sensitive to the action of MT and DOX in comparison with the ascitic form.

Anti-inflammatory action. It is well known that TR and its derivatives are potent anti-inflammatory and immunosuppressive agents $(1,2)$. Thus, we investigated the anti-inflammatory action of the compound MT in comparison with that of TR, using the murine model of systemic inflammation induced by the lipopolysaccharide (LPS) from E. coli. LPS is the exogenous ligand of Toll-like receptors and is responsible for the activation of key inflammatory pathways. It increases the expression of the genes responsible for the synthesis of, mainly, cytokines, which are involved in the development of the inflammatory and autoimmune processes (29). The results of the analysis of cytokine content in treated and untreated mice are given in Fig. 6.

It was found that TR, unlike MT, decreased the levels of cytokines in the serum of experimental animals measured $1.5 \mathrm{~h}$ after their administration, as for treatment with Dexamethasone

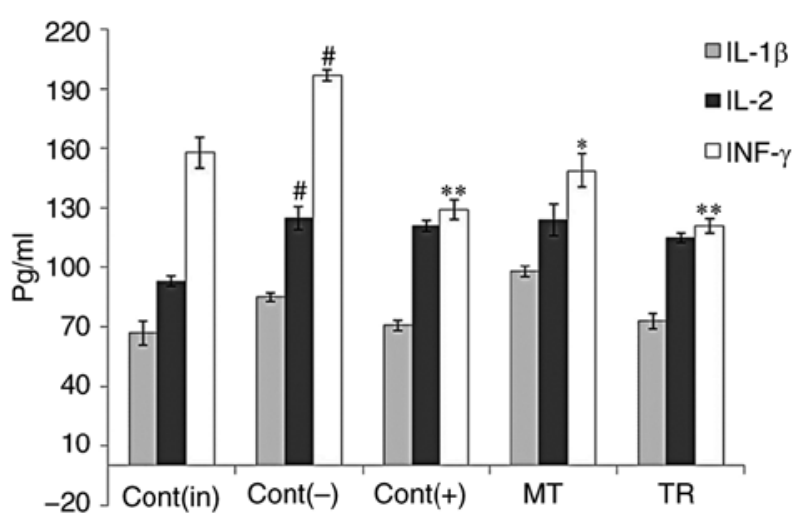

Figure 6. Effect of TR and MT on the levels of the cytokines IL-1 $\beta, 2$ and IFN- $\gamma$ in blood serum. Cont(in), intact control; Cont(-), negative control; Cont(+), positive control (treatment with anti-inflammatory drug dexamethasone); MT, group treated with mostotrin; TR, group of animals treated with tryptanthrin. Columns show the concentrations of pro-inflammatory cytokines, in $\mathrm{pg} / \mathrm{ml}$. Results are presented as mean $\pm \mathrm{SEM}, \mathrm{n}=7$ for each group. $\mathrm{P}$-values are labelled as ${ }^{*} \mathrm{P}<0.05,{ }^{* *} \mathrm{P}<0.01$ vs. negative control group, and ${ }^{\#} \mathrm{P}<0.05$ vs. intact group (Tukey's test).

(Fig. 6). Under the same conditions, MT hardly influenced the levels of IL-1 $\beta$ and 2 , and showed a lower inhibition of IFN- $\gamma$ levels than TR. Thus, MT is a weaker immunosuppressive agent in comparison with TR.

\section{Discussion}

In the present study, we designed and performed the synthesis of so-called MT, a new water-soluble TR derivative. To the best our knowledge, MT is the first compound of the TR series with such properties. Its X-ray analysis has shown that the obtained compound MT contains an additional pseudo-cycle formed by an intramolecular hydrogen bond, in contrast with TR. The evaluation of its physiological action demonstrates that it has 5-fold lower toxicity than TR. Moreover, this modification led to significant changes of antimicrobial, cytotoxic, antitumor and immunosuppressive activities of MT in comparison with TR.

Parent TR showed a broad spectrum of antimicrobial and antifungal activities (1). The efficiency of TR against 
the pathogenic fungus Trichophyton mentagrophytes was comparable to that of the antibiotic griseofulvin (30). An oxime of TR was reported to be highly active against the bacterium E. coli (31). Compound TR also inhibits the growth of Helicobacter pylori, the main microbial factor responsible for the development of gastric ulcers (32). Some derivatives of TR are much more active than TR against pathogenic bacteria and fungi (33). The greatest attention to compounds belonging to this class has been caused by their anti-tuberculosis properties (34), as well as their efficacy against the flagellated protozoa Trypanosoma brucei, which is transmitted by tsetse flies and cause a sleeping sickness in humans and a related disease in cattle (35). In contrast to TR, antibacterial activity of MT in relation to the majority of chosen bacteria and the fungus was lower, but MT had high antibacterial activity against Mycobacterium spp. According to Kamal et al (36), an in silico molecular docking study demonstrated that TR and its derivatives can inhibit the activity of the enoyl-ACP reductase (InhA), an enzyme essential for the survival of Mycobacterium spp. InhA is one of the key enzymes involved in the synthesis of mycolic acid, which is an important component of Mycobacterium spp. cell walls (37). Thus, InhA may be suggested as a potential antimicrobial target of compound MT.

Previous findings have shown that TR itself, as well as some of its derivatives and/or analogues, demonstrate cytotoxic action against various lines of human and animal tumour cells in vitro $(1,24-26)$. In the evaluation of cytotoxic activity of MT and TR in the present study it was demonstrated that MT showed higher anti-proliferative activity, when compared with TR, against HCT-116, K-562 and MCF-7 tumour cell lines. Thus, MT exhibits antimicrobial activity and shows cytotoxic effects against different human tumour cell lines in vitro. Of those strains of microorganisms and tumour cell cultures tested, mycobacteria and leukaemia cells are most sensitive to the action of MT. The DNA binding capability of MT (unlike TR) may be connected with a possible mechanism of its cytotoxic action.

MT possesses in vivo anti-tumour action on Ehrlich's carcinoma models either alone or, notably, in combination with DOX. In the ascitic form of Ehrlich adenocarcinoma it was shown that treatment with a combination of MT and DOX was more effective in comparison with monotherapy of MT and DOX. Thus, solid Ehrlich's adenocarcinoma is less sensitive to the action of MT and DOX in comparison with the ascitic form. It is well known that the ascitic form of Ehrlich's adenocarcinoma responds significantly better to i.p. treatment with anti-tumour drugs than the solid form (38). To understand the mechanism of action of MT against various tumour types in future studies the collection of histopathological samples would be valuable. We consider that the results concerning joint application of MT with DOX (in vivo experiments) are of biomedical significance. The obtained data were also compared with previous results on the examination of anti-tumour activity of the parent compound TR and remedies based on it, such as the so-called 'Courochitin' $(11,26)$. Of note, the latter also inhibited tumour growth in mice with ascitic Ehrlich carcinoma at oral administration, particularly in combination with the antitumour drug 'Cyclophosphan' (11), but its effect was less significant. It also was noted that modification of the structure of TR plays an important role in the development of new anti-tumour agents, with high efficacy against DOX- and etoposide-resistant tumour cells (26).

It should be noted that MT is a weaker immunosuppressive agent in comparison with TR. It is well known that anti-inflammatory and immunosuppressive activities of TR and its derivatives are believed to be the result of their multiple action on Toll-like receptors and signalling pathways involved in the development of inflammatory reactions, for example, nuclear factor- $\kappa \mathrm{B}(\mathrm{NF}-\kappa \mathrm{B})$ and signal transducer and activator of transcription (STAT), as well as its activity on the expression level of enzymes such as cyclooxygenase-2 (COX-2) and 5-lipooxygenase (5-LOX) (39-41). Consequently, in the murine model of systemic inflammation induced by LPS TR, TR inhibited the release of IL- $1 \beta$, IL- 2 and INF- $\gamma$. In particular, a pronounced decrease in the level of INF- $\gamma$ was detected. INF- $\gamma$ is known as an important pro-inflammatory cytokine, which activates the NF- $\kappa \mathrm{B}$ and JAK-STAT pathways, and also COX-2 and 5-LOX activity $(42,43)$. By contrast, MT exerts a lower immunosuppressive effect via inhibition of proinflammatory cytokine levels in plasma compared to TR. This may be an important positive factor for the treatment of cancer and/or tuberculosis with MT, but these findings require further confirmation. Thus, MT may be considered a promising anti-tumour and antimicrobial hit compound.

\section{Acknowledgements}

Not applicable.

\section{Funding}

G.B. Elyakov Pacific Institute of Bioorganic Chemistry funding from the Russian Ministry of Science and Higher Education.

\section{Availability of data and materials}

The analysed datasets generated during the present study are available from the corresponding author on reasonable request.

\section{Authors' contributions}

AP, AK, AS and VS conceived and designed the experiments and wrote the manuscript; AK, OS, TM, NG, LD, DK, PD, AG and AU performed the experiments and analysed the data. All the authors have read and approved the final version of this manuscript.

\section{Ethics approval and consent to participate}

The animal study was performed in accordance with the European Convention for the Protection of Vertebrate Animals, Directives 86/609/EEC [Council of Europe European Convention for the Protection of Vertebrate Animals used for Experimental and Other Scientific Purposes. Strasbourg: 1986, Accessed August 28,2018] 18.III.1986. Council of Europe, ETS No. 123, European Convention for the humane methods for the animal welfare and maintenance [Directive 2010/63/EU on the protection of animals used for scientific purposes EN. Official 
Journal of the European Union, L 276/33-276/79 (20.10.2010)], the National Standard of the Russian Federation R 53434-2009 'Good Laboratory Practice' (National state standard GOST P 53434-2009 the Russian Federation standard 'The principles of Good Laboratory Practice' approved and put into effect by the Order of the Federal Agency for Technical Regulation and Metrology of December 2, 2009, No. 544) and approved by Ethics Committee of Animal Experimentation of G.B Elyakov Pacific Institute of Bioorganic Chemistry of the Russian Academy of Science.

\section{Patient consent for publication}

Not applicable.

\section{Competing interests}

The authors declare that they have no competing interests.

\section{References}

1. Jahng Y: Progress in the studies on tryptanthrin, an alkaloid of history. Arch Pharm Res 36: 517-535, 2013.

2. Wagner-Döbler I, Rheims H, Felske A, El-Ghezal A, Flade-Schröder D, Laatsch H, Lang S, Pukall R and Tindall BJ: Oceanibulbus indolifex gen. nov., sp. nov., a North Sea alphaproteobacterium that produces bioactive metabolites. Int J System Evol Microbial 54: 1177-1184, 2004

3. Vlachos C, Schulte BM, Magiatis P, Adema GJ and Gaitanis G: Malassezia-derived indoles activate the aryl hydrocarbon receptor and inhibit Toll-like receptor-induced maturation in monocyte-derived dendritic cells. Br J Dermatol 167: 496-505, 2012

4. Cheng HM, Wu YC, Wang Q, Song M, Wu J, Chen D, Li K Wadman E, Kao ST, Li TC, et al: Clinical efficacy and IL-17 targeting mechanism of Indigo naturalis as a topical agent in moderate psoriasis. BMC Complement Altern Med 17: 439, 2017.

5. Kaur R, Manjal SK, Rawal RK and Kumar K: Recent synthetic and medicinal perspectives of tryptanthrin. Bioorg Med Chem 25: 4533-4552, 2017.

6. Mitcher LA and Baker W: Tuberculosis: A search for novel therapy starting with natural products. Med Res Revs 18 363-374, 1998.

7. Krivogorsky B, Grundt P, Yolken R and Jones-Brando L: Inhibition of Toxoplasma gondii by indirubin and tryptanthrin analogs. Antimicrob Agents Chemother 52: 4466-4469, 2008.

8. Mitscher LA, Wong WC, De Meulenaere T, Sulko J and Drake S: Antimicrobial agents from plants. New synthesis and bioactivity of tryptanthrin (indolo[2,1-b]quinazoline-6,12-dione) and its derivatives. Heterocycles 15: 1017-1021, 1981.

9. Popov AM, Gafurov YM, Moskovkina TV, Kachanov AV, Krivoshapko ON, Petrovicheva SE and Stonik VA: Kourokhitin, a potential drug containing two active substances. Dokl Biochem Biophys 426: 131-133, 2009.

10. Popov AM, Nedashkovskaya OI, Gafurov YM and Moskovkina TV: Antimicrobial activity of «Kourochitin» preparation. Russ J Biopharm 3: 19-22, 2011.

11. Popov AM, Shtoda YP, Krivoshapko ON, Gafurov YM and Moskovkina TV: Wound healing activity of different ointment forms of quinazoline alkaloid tryptanthrin. Russ J Biopharm 4 21-24, 2012.

12. Popov AM, Krivoshapko ON, Tsybulsky AV, Shtoda YP, Klimovich AA, Gafurov YM and Artyukov AA: Therapeutic activity of preparation «Kourochitin» at modeling allergic dermatitis. Russ J Biopharm 7: 24-30, 2015.

13. Popov AM, Osipov AN, Korepanova EA, Krivoshapko ON, Shtoda YP and Klimovich AA: Study of antioxidant and membranotropic activities of quinazoline alkaloid tryptanthrin using different model systems. Biofizika 60: 700-707, 2015 (In Russian).

14. Klimovich AA, Popov AM, Krivoshapko ON, Shtoda YP and Tsybulsky AV: A comparative assessment of the effects of alkaloid tryptanthrin, rosmarinic acid, and doxorubicin on the redox status of tumour and immune cells. Biophysics 62: 588-594, 2017.
15. Moskovkina TV, Denisenko VA, Kalinovskii AI and Stonik VA: Synthesis of substituted tryptanthrins via oxidation of isatin and its derivatives. Russ J Org Chem 49: 1740-1743, 2013.

16. Moskovkina TV, Kalinovskii AI and Makhan'kov VV: Synthesis of tryptanthrin (couroupitine) derivatives by reaction of substituted isatins with phosphoryl chloride. Rus J Org Chem 48: 123-126, 2012.

17. Bruker: APEX2. Bruker AXS Inc., Madison, WI, 2012.

18. Sheldrick GM: SHELXT-integrated space-group and crystal-structure determination. Acta Crystallogr A Found Adv 71: 3-8, 2015

19. Tikhomirov AS, Tsvetkov VB, Kaluzhny DN, Volodina YL, Zatonsky GV, Schols D and Shchekotikhin AE: Tri-armed ligands of G-quadruplex on heteroarene-fused anthraquinone scaffolds: Design, synthesis and pre-screening of biological properties. Eur J Med Chem 159: 59-73, 2018.

20. McGhee JD and von Hippel PH: Theoretical aspects of DNA-protein interactions: Co-operative and non-co-operative binding of large ligands to a one-dimensional homogeneous lattice. J Mol Biol 86: 469-489, 1974.

21. Akhila JS, Deepa S and Alwar MC: Acute toxicity studies and median lethal dose. Curr Sci 93: 917-920, 2007.

22. Elsherbinya NM, Younisb NN, Shaheenc MA and Elseweidy MM: The synergistic effect between vanillin and doxorubicin in Ehrlich ascites carcinoma solid tumour and MCF-7 human breast cancer cell line. Pathol Res Pract 212: 767-777, 2016.

23. Fedeli W and Mazza F: Crystal structure of tryptanthrin (indolo[2,1-b]quinazoline-6,12-dione. J Chem Soc Perkin Trans 2: 1621-1623, 1974.

24. Kimoto T, Hino K, Koya-Miyata S, Yamamoto Y, Takeuchi M, Nishizaki Y, Micallef MJ, Ushio S, Iwaki K, Ikeda M and Kurimoto M: Cell differentiation and apoptosis of monocytic and promyelocytic leukemia cells (U-937 and HL-60) by tryptanthrin, an active ingredient of Polygonum tinctorium Lour. Pathol Int 51: 315-325, 2001.

25. Yu ST, Chern JW, Chen TM, Chiu YF, Chen HT and Chen YH: Cytotoxicity and reversal of multidrug resistance by tryptanthrin-derived indoloquinazolines. Acta Pharmacol Sin 31: 259-264, 2010

26. Jao CW, Lin WC, Wu YT and Wu PL: Isolation, structure elucidation, and synthesis of cytotoxic tryptanthrin analogues from Phaius mishmensis. J Nat Prod 71: 1275-1279, 2008.

27. Duncan M,DeLuca T, Kuo HY, Yi M, Mrksich M and Miller WM: SIRT1 is a critical regulator of K562 cell growth, survival, and differentiation. Exp Cell Res 344: 40-52, 2016

28. Deo KM, Pages BJ, Ang DL, Gordon CP and Aldrich-Wright JR: Transition metal intercalators as anticancer agents-recent advances. Int J Mol Sci 17: 1818, 2016.

29. Ito W, Takeda M, Ueki S, Tanigai T, Kayaba $\mathrm{H}$ and Chihara J: Effect of the hepatocyte growth factor on allergic inflammatory cells. Int Arch Allergy Immunol 152 (Suppl 1): S96-S100, 2010.

30. Honda G, Tabata $\mathrm{M}$ and Tsuda $\mathrm{M}$ : The antimicrobial specificity of tryptanthrin. Planta Med 37: 172-174, 1979.

31. Bandekar PP, Roopnarine KA, Parekh VJ, Mitchell TR, Novak MJ and Sinden RR: Antimicrobial activity of tryptanthrins in Escherichia coli. J Med Chem 53: 3558-3565, 2010.

32. Kataoka M, Hirata K, Kunikata T, Ushio S, Iwaki K, Ohashi K, Ikeda $\mathrm{M}$ and Kurimoto $\mathrm{M}$ : Antibacterial action of tryptanthrin and kaempferol, isolated from the indigo plant (Polygonum tinctorium Lour.), against Helicobacter pylori-infected Mongolian gerbils. J Gastroenterol 36: 5-9, 2001.

33. Kawakami J, Matsushima N, Ogawa Y, Kakinami H, Nakane A, Kitahara $\mathrm{H}$, Nagaki $\mathrm{M}$ and Ito S: Antibacterial and antifungal activities of tryptanthrin derivatives. Trans Mat Res Soc Japan 36: 603-606, 2011.

34. Hwang JM, Oh T, Kaneko T, Upton AM, Franzblau SG, Ma Z, Cho SN and Kim P: Design, synthesis, and structure-activity relationship studies of tryptanthrins as antitubercular agents. J Nat Prod 76: 354-367, 2013

35. Scovill J, Blank E, Konnick M, Nenortas E and Shapiro T: Antitrypanosomal activities of Tryptanthrins. Antimicrob Agents Chemother 46: 882-883, 2002.

36. Kamal A, Reddy BV, Sridevi B, Ravikumar A, Venkateswarlu A, Sravanthi G, Sridevi JP, Yogeeswari P and Sriram D: Synthesis and biological evaluation of phaitanthrin congeners as anti-mycobacterial agents. Bioorg Med Chem Lett 25: 3867-3872, 2015.

37. Chollet A, Maveyraud L, Lherbet C and Bernardes-Génisson V: An overview on crystal structures of InhA protein: Apo-form, in complex with its natural ligands and inhibitors. Eur J Med Chem 146: 318-343, 2018 
38. Sugiura K: Relative sensitivity of the solid and ascites forms of sarcoma 180 and Ehrlich carcinoma to inhibitory compounds. Ann N Y Acad Sci 76: 575-585, 1958.

39. Ishihara T, Kohno K, Ushio S, Iwaki K, Ikeda M and Kurimoto M: Tryptanthrin inhibits nitric oxide and prostaglandin E(2) synthesis by murine macrophages. Eur.J Pharmacol 407: 197-204, 2000.

40. Pergola C, Jazzar B, Rossi A, Northoff H, Hamburger M, Sautebin L and Werz O: On the inhibition of 5-lipoxygenase product formation by tryptanthrin: Mechanistic studies and efficacy in vivo. Br J Pharmacol 165: 765-776, 2012.

41. Han NR, Kim HM and Jeong HJ: Thymic stromal lymphopoietin is regulated by the intracellular calcium. Cytokine 59: 215-217, 2012.

42. Hernandez-Santana YE, Giannoudaki E, Leon G, Lucitt MB and Walsh PT: Current perspectives on the interleukin-1 family as targets for inflammatory disease. Eur J Immunol 49: 1306-1320, 2019.
43. Pathania AS, Kumar S, Guru SK, Bhushan S, Sharma PR, Aithagani SK, Singh PP, Vishwakarma RA, Kumar A and Malik F: The synthetic tryptanthrin analogue suppresses STAT3 signaling and induces caspase dependent apoptosis via ERK Up regulation in human leukemia HL-60 cells. PLoS One 9: e110411, 2014.

(c) (i) $\odot$ This work is licensed under a Creative Commons Attribution-NonCommercial-NoDerivatives 4.0 International (CC BY-NC-ND 4.0) License. 